\title{
Maternal Health and Care-Seeking Behavior In Bangladesh: Findings from a National Survey
}

\begin{abstract}
CONTEXT: Although the reduction of maternal mortality levels is a key Millennium Development Goal, communitybased evidence on obstetric complications and maternal care-seeking behavior remains limited in low-resource countries.
\end{abstract}

METHODS: This study presents an overview of key findings from the 2001 Bangladesh Maternal Health Services and Maternal Mortality Survey of ever-married women aged 13-49. The survey collected data on the prevalence of obstetric complications, women's knowledge of life-threatening complications, treatment-seeking behavior and reasons for delay in seeking medical care.

RESULTS: Bangladeshi women report low but increasing use of antenatal care, as well as low rates of delivery in a health facility or with the assistance of a skilled provider. Although almost half of women reported having one or more complications during pregnancy that they perceived as life threatening, only one in three sought treatment from a qualified provider. More than three-fourths of women with the time-sensitive complications of convulsions or excessive bleeding either failed to seek any treatment or sought treatment from an unqualified provider. The principal reason cited for failing to seek care for life-threatening complications was concern over medical costs, and pronounced socioeconomic disparities were found for maternal care-seeking behavior in both urban and rural Bangladesh.

CONCLUSIONS: Despite these gaps in access to skilled delivery and effective emergency obstetric care, some progress has been made in reducing maternal mortality levels. Improved obstetric care and declining levels of fertility and unwanted pregnancy may have played critical roles in addressing the maternal health care needs of Bangladeshi women. International Family Planning Perspectives, 2007, 33(2):75-82

\section{BACKGROUND}

Over the past two decades, impressive strides have been made in reducing levels of infant and childhood mortality and in increasing levels of contraceptive use in developing countries. In contrast, progress in reducing levels of maternal mortality and in making pregnancy and childbearing safer for women, despite being a central element of the Millennium Development Goals, has been much slower. ${ }^{1}$ Although exact figures remain elusive, an estimated 525,000 women, almost all from developing countries, continue to die each year from maternal causes. ${ }^{2}$

In Bangladesh, the reduction in levels of maternal mortality and improvement of maternal health have been central policy and program goals since the fourth Population and Health Programme, which began in 1992. Efforts to address these issues have recently gained considerable momentum with the formulation of the National Strategy for Maternal Health. ${ }^{3}$ This strategy emphasizes the provision of emergency obstetric care, and is predicated on the "three delays" framework of factors that affect safe motherhood service utilization and outcomes: delays in making the decision to seek care, in reaching a medical facility and in receiving adequate treatment or management at the facility. ${ }^{4}$

Evaluation of the overall progress in improving maternal health in Bangladesh (and elsewhere) has been ham- pered by the absence of suitable data. Facility-based assessments provide a picture of the availability, functioning and caseloads of maternal health facilities, but only for the select minority of women who utilize such services. ${ }^{5}$ In contrast, population-based surveys, such as the Demographic and Health Surveys (DHS), provide useful but generally limited data on basic aspects of maternal health behavior related to antenatal and delivery care. ${ }^{6,7}$ To address these information gaps, in 2001 the Bangladesh Maternal Health Services and Maternal Mortality Survey (BMMS) collected national data on the levels and causes of maternal and nonmaternal mortality; women's experience with and perceived severity of maternal complications; utilization of services for antenatal, delivery, postpartum and emergency obstetric care; delays in seeking emergency obstetric care; and indicators of the use of maternal health services.

As the first national population-based survey of its kind in Bangladesh, the BMMS provides a unique picture of maternal health and care-seeking behavior in a low-resource setting. A clear strength of the BMMS is its multipurpose nature, generating nationally representative data on maternal mortality levels, ${ }^{8,9}$ maternal health-seeking behavior and women's understanding of, experience with and resolution of specific maternal complications. A second unique feature of the BMMS lies in its ability to provide a
By Michael A.

Koenig, Kanta

Jamil, Peter K.

Streatfield, Tulshi

Saha, Ahmed

Al-Sabir, Shams El

Arifeen, Ken Hill

and Yasmin Haque

Michael A. Koenig is associate professor, Bloomberg School of Public Health, Johns Hopkins University, Baltimore, MD, USA. Kanta Jamil is program coordinator for research, U.S. Agency for International Development, Dhaka, Bangladesh. Peter K. Streatfield is head, Health and Demographic Surveillance Unit, and Shams El Arifeen is head, Child Health Unit, both at the International Centre for Diarrhoeal Disease Research, Bangladesh, Dhaka. Tulshi Saha is survey statistician, National Institute on Alcohol Abuse and Alcoholism, Bethesda, MD, USA. Ahmed Al-Sabir is research director, National Institute of Population Research and Training, Dhaka. Ken Hill is associate director, Harvard Center for Population and Development Studies, Cambridge, MA, USA. Yasmin Haque is senior program officer, UNICEF, Colombo, Sri Lanka. 


\begin{tabular}{|c|c|}
\hline Complication & Definition \\
\hline Preeclampsia ( $\geq 1$ symptom) & $\begin{array}{l}\text { Severe headache } \\
\text { Blurred vision or seeing "darkness" after rising from } \\
\text { a sitting position } \\
\text { High blood pressure } \\
\text { Swelling in hands and feet or water retention }\end{array}$ \\
\hline Excessive bleeding & Bleeding that soaks clothes \\
\hline High fever with discharge & $\begin{array}{l}\text { Foul-smelling vaginal discharge and high fever (both } \\
\text { must be present) }\end{array}$ \\
\hline Eclampsia & Convulsions during pregnancy, delivery or postdelivery \\
\hline $\begin{array}{l}\text { Malpresentation or } \\
\text { prolonged/obstructed labor }\end{array}$ & $\begin{array}{l}\text { Body part other than the head emerged first } \\
\text { Prolonged labor } \\
\text { Baby did not emerge after uterus had contracted } \\
\text { and cervix had opened }\end{array}$ \\
\hline Other & $\begin{array}{l}\text { Ruptured uterus } \\
\text { Retained or partially expelled placenta } \\
\text { Tetanus (convulsions with difficulty swallowing } \\
\text { or stiffening of jaw or neck) } \\
\text { Vomiting, diarrhea, dysentery or gastric problem } \\
\text { Premature leakage of uterine membranes } \\
\text { General weakness or other complication }\end{array}$ \\
\hline
\end{tabular}

population-based perspective on emergency obstetric care needs and related behavior-including the perceived occurrence and severity of obstetric complications and associated treatment-seeking behavior. Population-based studies complement approaches that use facility-based process indicators-especially in settings where most deliveries take place outside of health facilities-by including respondents who do not seek treatment at facilities. ${ }^{10} \mathrm{~A}$ final strength of the BMMS is that it identifies and quantifies the specific delays in seeking emergency obstetric care from a sufficiently large sample to permit disaggregation by types of complications.

A potential limitation of the BMMS and other retrospective studies is their reliance on women's self-reports regarding the occurrence and severity of obstetric complications; most studies have shown that self-reports may have low correspondence with medically diagnosed morbidi-

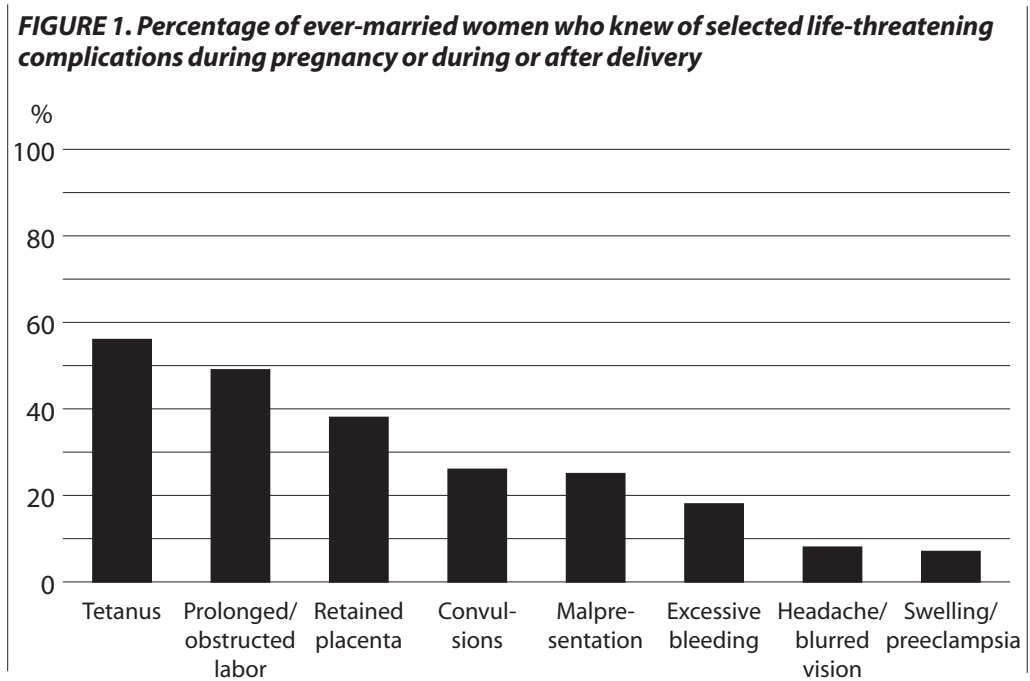

ty. ${ }^{11-13}$ Thus, while the BMMS estimates of obstetric complications and morbidity should be treated with caution, such information is critical to assessing and understanding women's treatment-seeking behavior, which depends primarily on perceptions of these complications and their associated severity. ${ }^{10,14}$ The value of future surveys similar to the BMMS would be enhanced by the concomitant collection of maternal health facility data in surrounding areas, and by more detailed data on maternal health care costs and women's perceptions of the access to and the quality of such health services.

\section{METHODS AND DATA}

The BMMS was conducted in all six divisions of Bangladesh using a two-stage sampling approach. Wards and unions served as the primary sampling units in urban and rural areas, respectively. In the first stage, 808 primary sampling units were chosen (the probability being proportional to their size), from which 1,616 secondary sampling clusters were systematically selected. All ever-married women aged 13-49 were eligible; a total of 104,323 households and 103,796 eligible women were interviewed, representing a response rate of $97 \% .^{8}$ This sample size was calculated to yield accurate national estimates of maternal mortality rates.

The BMMS consisted of three questionnaires. The household questionnaire collected information on selected social and demographic characteristics of all listed persons, household characteristics and deaths to household members during the three-year period prior to the survey. The verbal autopsy questionnaire was administered to the most knowledgeable family member to obtain information on all deaths to females aged 13-49 reported during the same three-year period. This interview consisted of both structured and open-ended questions on cause of death. All evermarried women aged 13-49 were administered the woman's questionnaire, which asked about, among other items, their socioeconomic and demographic characteristics, reproductive history and knowledge of specific life-threatening obstetric complications. For all live births and stillbirths that had occurred during the three years preceding the survey $(\mathrm{N}=40,657),{ }^{*}$ women were asked about antenatal, delivery and postdelivery care, as well as their experience of maternal health complications; associated treatmentseeking behavior. A team of medical and demographic experts compiled a list of Bangla terms used to describe specific complications; a summary of obstetric complications is presented in Table 1. The 7,613 women who reported that they were pregnant at the time of the BMMS were asked whether they had discussed or decided who would assist them during delivery.

When more than one complication perceived as life threatening was reported, only the most recent was considered ( $\mathrm{N}=18,117)$. When both life-threatening and nonlife-threatening complications were reported, the most recent life-threatening complication was considered as the

*Abortions and miscarriages were not asked about in the BMMS. 
reference complication. For women who reported no lifethreatening complications, treatment-seeking behavior for the last non-life-threatening complication was examined $(\mathrm{N}=6,501)$. This selection process resulted in an overrepresentation of maternal complications that were perceived as life threatening in the analysis of treatment-seeking behavior, and for this reason, the data for life-threatening and non-life-threatening complications have been estimated separately.

The BMMS was implemented under the authority of the Bangladesh National Institute of Population Research and Training, and was funded by the U.S. Agency for International Development, Bangladesh. Data collection was conducted by two Bangladeshi organizations-Associates for Community and Population Research, and Mitra and Associates-both of which possessed extensive experience in large-scale demographic and health research. Each agency was responsible for data collection in three of the six divisions of Bangladesh. ORC Macro provided technical assistance and support, and the International Centre for Diarrhoeal Disease Research, Bangladesh, and Johns Hopkins University assisted with questionnaire design and data analysis. The questionnaire was pretested in November 2000, and revisions were made to both the original questionnaire and the Bangla translations. Data collection was carried out by 50 interview teams, with each team consisting of four female interviewers, a female field editor who reviewed completed questionnaires and a male supervisor. Independent quality control teams from both data-collecting organizations monitored fieldwork quality throughout the collection period, from January to June 2001.

\section{RESULTS}

\section{Antenatal Care}

Women reported having received antenatal care from a provider for $48 \%$ of all live births and stillbirths in the three years preceding the survey. In more than $85 \%$ of these cases, care was obtained from medically trained providers. Comparison with the two previous Bangladesh Demographic and Health Surveys indicates a steady increase in the proportion of women who sought antenatal care from a qualified provider-from 30\% in the 1996-1997 DHS to $35 \%$ in the 1999-2000 DHS and 41\% in the 2001 BMMS. $* 6,15$

The World Health Organization (WHO) recommends a minimum of four antenatal care visits, with the initial visit occurring by the fourth month of pregnancy. In our study, the number of antenatal visits to any provider was lowin only $12 \%$ of recent pregnancy outcomes had women made the recommended four antenatal visits. Moreover, the median time of first visit was at 5.4 months of pregnancy, and in only one in seven cases did women initiate antenatal care during the first trimester. Although $84 \%$ of women reported having received advice on diet, only $54 \%$ were told where to go in the event of maternal complications and just $45 \%$ were informed about the danger signs of complications.

\begin{tabular}{|c|c|c|c|c|}
\hline Complication & $\begin{array}{l}\text { During } \\
\text { gestation }\end{array}$ & $\begin{array}{l}\text { During } \\
\text { delivery }\end{array}$ & $\begin{array}{l}\text { After } \\
\text { delivery }\end{array}$ & $\begin{array}{l}\text { Any } \\
\text { stage }\end{array}$ \\
\hline \multicolumn{5}{|l|}{ No. } \\
\hline 0 & 54.2 & 65.4 & 76.2 & 39.4 \\
\hline$\geq 1$ & 45.8 & 34.6 & 23.8 & 60.6 \\
\hline \multicolumn{5}{|l|}{ Type } \\
\hline \multicolumn{5}{|l|}{ Preeclampsia } \\
\hline Excessive bleeding & 1.6 & 4.6 & 10.2 & 13.3 \\
\hline \multicolumn{5}{|l|}{ High fever with } \\
\hline discharge & 2.6 & 0.7 & 2.0 & 4.4 \\
\hline Convulsions & 1.4 & 1.7 & 3.1 & 5.4 \\
\hline \multicolumn{5}{|l|}{$\begin{array}{l}\text { Malpresentation or } \\
\text { prolonged/ }\end{array}$} \\
\hline obstructed labor & 0.0 & 21.9 & 0.0 & 21.9 \\
\hline Retained placenta & 0.0 & 2.2 & 2.8 & 4.7 \\
\hline Other* & 10.7 & 3.1 & 4.4 & 14.8 \\
\hline Missing & 0.2 & 0.3 & 0.6 & 0.0 \\
\hline
\end{tabular}

*Includes ruptured uterus, tetanus, vomiting, diarrhea, dysentery, gastric problem, premature leakage of uterine membranes, general weakness and other complications. Notes: $\mathrm{N}=40,657$. Miscarriages and abortions not included. Multiple responses allowed.

\section{Delivery and Postdelivery Care}

Planning for delivery is still not commonplace among pregnant Bangladeshis. Almost two-thirds of the 7,613 currently pregnant women had neither discussed nor made a decision regarding assistance at delivery; even among those in their third trimester, more than half had not reached a decision. Among those who had made a decision, 83\% intended to have a medically untrained person assist in delivery.

The BMMS data show that most deliveries still occur at home and are attended by medically unskilled birth attendants. Among all live births and stillbirths in the three years preceding the survey, 91\% took place outside of a health facility. Six percent of facility-based deliveries occurred at a government hospital, upazila (administrative unit) health complex, or maternal and child welfare center, and $3 \%$ at a private hospital or clinic. Only $12 \%$ of deliveries were attended by a medically trained provider. Comparison of BMMS 2001 data with 1993-1994 DHS data ${ }^{16}$ reveals little change in the proportion of births assisted by a medically trained provider, in either urban or rural areas.

The BMMS found that the proportion of women reporting a cesarean delivery was 3\%, part of a modest upward trend (from 2\% in the 1999-2000 DHS) toward the WHO-recommended minimum of $5 \%$ of all deliveries. Yet this procedure is largely limited to women who reside in urban areas and in households of higher socioeconomic status. ${ }^{8}$ Other medical procedures at delivery are also quite infrequent: Two percent reported forceps delivery and 1\% reported having received a blood transfusion at their most recent delivery. Postnatal care for mothers and infants within 42 days of delivery was uncommon, with $11 \%$ and $15 \%$

*To achieve comparability between the BMMS and DHS samples, only live births during the three-year period preceding the surveys were considered for the antenatal care data. 

FIGURE 2. Among women reporting specific complications, percentage who perceived
those complications as life threatening

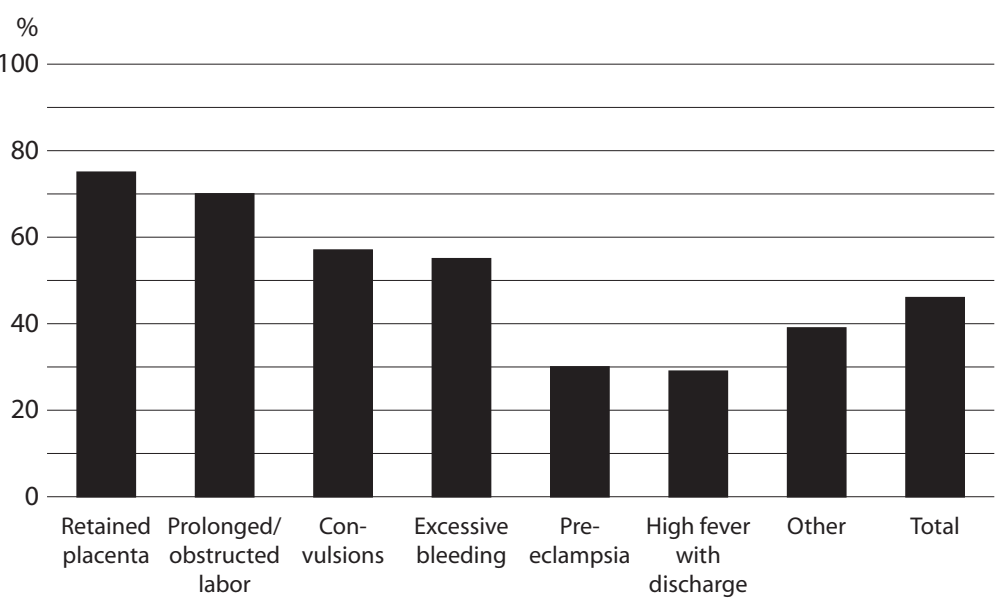

of mothers, respectively, reporting having obtained a postnatal checkup for themselves or for their baby from a medically trained provider.

\section{Obstetric Complications}

-Knowledge of complications. Overall, women's awareness of life-threatening complications during pregnancy, delivery and the postpartum period was quite low, although it varied considerably according to type of complication (Figure 1, page 76). Fifty-six percent of women cited tetanus and $49 \%$ cited prolonged or obstructed labor as potentially life-threatening conditions, while smaller proportions mentioned retained placenta (38\%) or malpresentation of the fetus (25\%). Although convulsions and excessive bleeding account for more than half of all maternal deaths in Bangladesh, ${ }^{8}$ only $26 \%$ and $18 \%$ of women, respectively, cited these complications. In all, $89 \%$ of surveyed women were able to name at least one obstetric complication, and $42 \%$ could name three or more (not shown).

- Prevalence of complications. The occurrence of at least one complication was reported in six of 10 live births and stillbirths. In $46 \%$ of these pregnancy outcomes, one or more complications occurred during gestation; in 35\%, during

\begin{tabular}{|c|c|c|c|c|}
\hline \multirow[t]{2}{*}{ Complication } & \multicolumn{2}{|c|}{ Life threatening } & \multicolumn{2}{|c|}{ Non-life-threatening } \\
\hline & No. & $\%$ & No. & $\%$ \\
\hline Any & 18,117 & 61.8 & 6,501 & 42.3 \\
\hline Preeclampsia ( $\geq 1$ symptom) & 4,622 & 55.6 & 3,707 & 34.4 \\
\hline Excessive bleeding & 2,653 & 65.1 & 605 & 38.5 \\
\hline High fever with discharge & 387 & 74.5 & 133 & 55.6 \\
\hline Convulsions & 961 & 76.6 & 91 & 59.3 \\
\hline $\begin{array}{l}\text { Malpresentation or prolonged/ } \\
\text { obstructed labor }\end{array}$ & 5,711 & 57.1 & 725 & 43.2 \\
\hline Retained placenta & 1,250 & 38.6 & 131 & 19.8 \\
\hline Other* & 2,533 & 84.3 & 1,109 & 69.6 \\
\hline
\end{tabular}

*Includes ruptured uterus, tetanus, vomiting, diarrhea, dysentery, gastric problem, premature leakage of uterine membranes, general weakness and other complications. delivery; and in 24\%, after delivery (Table 2, page 77). Convulsions and excessive bleeding, the two most important causes of maternal death, ${ }^{8}$ were reported in 5\% and 13\% of cases, respectively. As would be expected, the prevalence of specific complications varied by stage of pregnancy. The most commonly reported complication during pregnancy was preeclampsia (39\%); the most frequently cited complications during delivery were malpresentation or prolonged or obstructed labor (22\%) and preeclampsia (11\%). For the period immediately following delivery, excessive bleeding (10\%) and preeclampsia (8\%) were the complications cited most often.

Overall, women considered almost half of all the complications they reported to be potentially life threatening (Figure 2). The complications most likely to be perceived as life threatening were retained placenta $(75 \%)$, prolonged or obstructed labor (70\%), convulsions (57\%) and excessive bleeding ( $55 \%$ ).

- Treatment-seeking behavior. In 62\% of live births and stillbirths with a complication that was perceived as life threatening, women sought some form of treatment (Table 3). Treatment was most likely to have been sought by women with convulsions (77\%) and those with high fever and foulsmelling vaginal discharge (75\%), followed by those with excessive bleeding (65\%), malpresentation or prolonged or obstructed labor (57\%), and retained placenta (39\%). For all types of complications, levels of treatment seeking were consistently lower when they were not perceived as life threatening.

Only one in three women who perceived their condition as life threatening, however, received care from a qualified provider-24\% went outside of their home to seek care (19\% from facility-based providers and 5\% from providers not based at a facility) and $8 \%$ received services from providers who came to their home (Figure 3).* In contrast, 29\% sought care from an unqualified provider either at home or outside the home (24\% vs. $5 \%$ ). ${ }^{\dagger}$ Overall, almost equivalent proportions sought treatment within or outside the home (32\% vs. 30\%). Most home-based treatment, however, was from unqualified providers rather than qualified providers ( $24 \%$ vs. $8 \%$ ). As might be expected, the proportion of non-life-threatening complications for which treatment was sought from a qualified provider was even lower (22\%-not shown).

Among the reasons women gave for not seeking treatment for obstetric complications perceived as life threatening, the most prominent was cost-related considerations, cited by $44 \%$. The second most common reason was the perception that treatment was not necessary or that the condition was not serious (39\%). One possible explanation for this apparent discrepancy is that different family members were involved in evaluating the seriousness of the com-

*Qualified providers included doctors with medical degrees, nurses, midwives, paramedics, family welfare visitors, medical assistants and subassistant community medical officers.

+Unqualified providers included fieldworkers, traditional birth attendants, doctors without medical degrees and quacks, among others. 
plication; further, in-depth research on this issue is clearly warranted. Other service-related barriers to seeking care included transportation and access issues (12\%), family opposition (12\%) and concerns related to service quality (6\%; women could give multiple reasons).

- Delays in seeking treatment. An innovative feature of the 2001 BMMS was its attempt to assess and quantify delays in seeking treatment for obstetric complications, about which relatively little is known., ${ }^{4}, 17$ Respondents reporting one or more complications perceived as life threatening were asked about four possible delays associated with the reference complication: the delay in deciding to seek care, which can be subdivided into the delay in recognizing the complication and the delay between recognition and deciding to seek treatment; travel time to the treatment facility; and waiting time at the facility. There were 3,614 reference cases of convulsions or excessive bleeding, two conditions whose effective resolution depends on timely intervention and treatment.

Sixty-one percent of women who had convulsions or excessive bleeding recognized their condition within six hours of onset, whereas 29\% took six or more hours; the other $10 \%$ were unsure of the time elapsed (Figure 4). Half of the women decided to seek treatment in less than six hours; $18 \%$ took six or more hours to decide, and $32 \%$ sought no treatment. Twenty percent of women with these complications sought treatment outside the home, with threefourths of these reporting a travel time of less than an hour. Forty-seven percent sought treatment at home. Nearly nine in 10 of those who sought facility-based treatment were seen within an hour of reaching the facility. These findings may reflect self-selection among women who sought care from providers or facilities.

- Disparities in maternal care-seeking behavior. Socioeconomic data collected in the BMMS allow the calculation of a household wealth index and the creation of household wealth quintiles. ${ }^{18}$ There were wide disparities in maternal care-seeking behavior across the wealth quintiles, with use of health care increasing with rising socioeconomic status (Table 4, page 80). Among rural women, $22 \%$ of those in the lowest wealth quintile and $69 \%$ in the highest quintile reported having sought antenatal care from a medically trained provider; women in the highest quintile had odds more than three times as high as those in the lowest quintile of seeking such care (crude odds ratio, 3.2). Similarly, $19 \%$ of rural women in the lowest wealth quintile and 60\% in the highest quintile sought treatment for a life-threatening complication; the wealthiest women had elevated odds of doing so (3.2). Even greater disparities were seen for two other care-seeking behaviors: Those in the highest wealth quintile had eight times the odds of obtaining skilled delivery care ( $28 \%$ vs. $3 \%$ ) and nine times the odds of delivering at a health facility ( $21 \%$ vs. $2 \%$ ) as did those in the lowest quintile.

Although levels of maternal health care use were somewhat higher among urban women, similar differentials across wealth quintiles were evident. Even among the

FIGURE 3. Women's treatment-seeking behavior for most recent life-threatening maternal complications, by treatment site and provider training

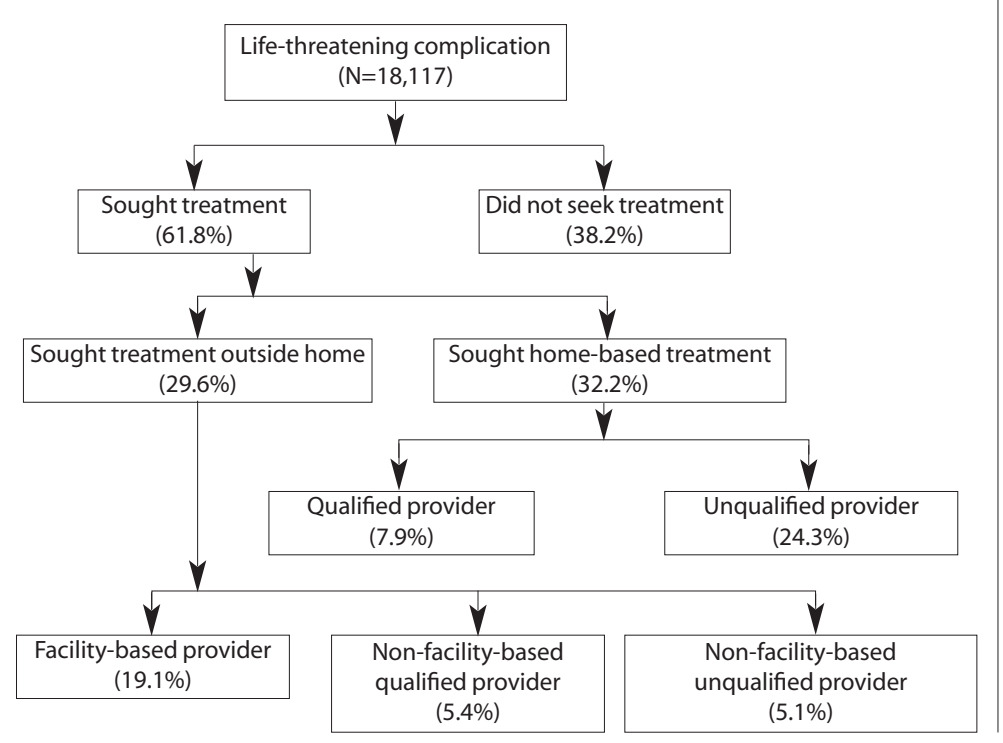

wealthiest urban and rural women, many did not obtain skilled delivery care, did not deliver at a facility or did not seek skilled treatment for life-threatening complications.

\section{DISCUSSION}

Over the last 15 years, the government of Bangladesh has engaged in a major effort to improve maternal health by developing and upgrading a network of essential obstetric

FIGURE 4. Percentage distribution of women with convulsions or excessive bleeding perceived as life threatening, by reported treatment-seeking behavior

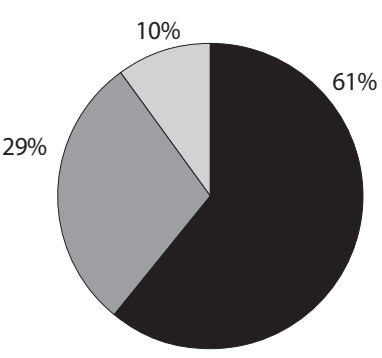

Recognition of complication

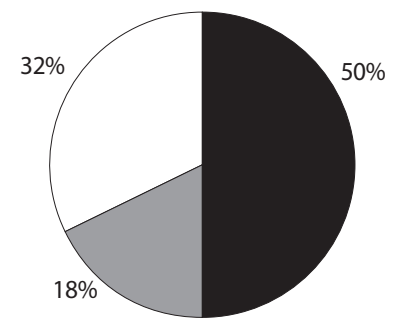

Decision to seek treatment

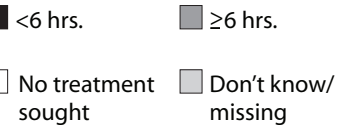

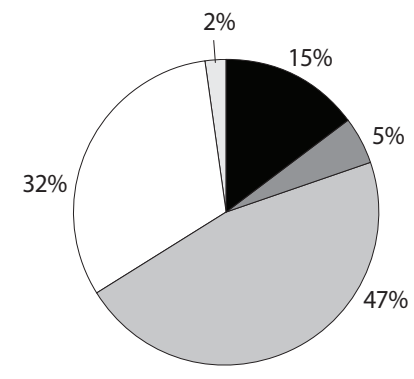

Travel time to facility/provider

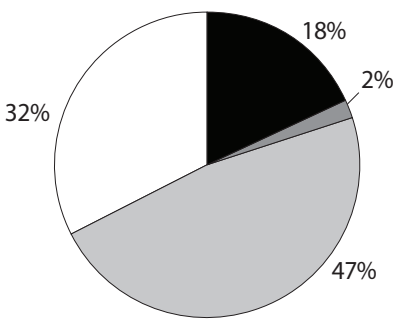

Waiting time at facility/provider

$<1 \mathrm{hr} . \quad \square \geq 1 \mathrm{hr}$.

Treatment sought at home

$\square$ No treatment $\square$ Don't know/ sought missing 


\begin{tabular}{|c|c|c|c|c|}
\hline $\begin{array}{l}\text { Residence and } \\
\text { wealth quintile }\end{array}$ & $\begin{array}{l}\text { Sought } \\
\text { antenatal care }\end{array}$ & $\begin{array}{l}\text { Obtained } \\
\text { delivery care }\end{array}$ & $\begin{array}{l}\text { Delivered at } \\
\text { health facility }\end{array}$ & $\begin{array}{l}\text { Sought treatment } \\
\text { for life-threatening } \\
\text { complication* }\end{array}$ \\
\hline Rural & $(\mathrm{N}=33,669)$ & $(\mathrm{N}=33,669)$ & $(\mathrm{N}=33,669)$ & $(\mathrm{N}=14,936)$ \\
\hline Lowest & 21.7 & 3.4 & 2.3 & 18.9 \\
\hline Second & 28.3 & 5.2 & 3.8 & 24.4 \\
\hline Middle & 35.9 & 7.2 & 5.4 & 30.3 \\
\hline Fourth & 48.3 & 11.5 & 8.4 & 41.3 \\
\hline Highest & 68.7 & 27.7 & 21.2 & 60.1 \\
\hline Crude odds ratio & 3.2 & 8.1 & 9.2 & 3.2 \\
\hline Urban & $(\mathrm{N}=6,989)$ & $(\mathrm{N}=6,989)$ & $(\mathrm{N}=6,989)$ & $(\mathrm{N}=3,181)$ \\
\hline Lowest & 27.0 & 5.3 & 4.0 & 28.0 \\
\hline Second & 38.2 & 6.6 & 4.5 & 30.0 \\
\hline Middle & 47.1 & 6.6 & 6.6 & 40.9 \\
\hline Fourth & 56.6 & 11.5 & 13.2 & 50.3 \\
\hline Highest & 82.9 & 51.0 & 43.1 & 77.2 \\
\hline Crude odds ratio & 3.1 & 9.6 & 10.8 & 2.8 \\
\hline
\end{tabular}

*The reference complication was the most recent one. †Compares the highest quintile to the lowest quintile (the reference group). imity to a facility or ability to pay for treatment among the minority of women who actually made it to a facility; the major programmatic concerns with treatment seeking instead appear to be the large proportions of women who either did not seek any form of treatment for such complications or sought treatment from medically unqualified providers.

Cost concerns are an important barrier to seeking emergency obstetric care in Bangladesh. Data from the BMMS identified cost as the most commonly cited reason for not seeking treatment; cost also emerged as a central concern in a separate analysis of BMMS verbal autopsy data of factors contributing to maternal death. ${ }^{19}$ The marked socioeconomic disparities in all aspects of maternity careincluding emergency obstetric care-observed in this and other studies from Bangladesh ${ }^{20}$ provide further evidence of the importance of financial considerations and barriers. Although public sector maternity care services are officially free in Bangladesh, some studies have documented the myriad hidden costs to patients associated with "free" obstetric care (such as hospital fees, corruption and medical supplies), which frequently result in an untenable financial burden to families. ${ }^{21,22}$ Policy priorities for improving maternal care should include testing approaches to lessen the financial burden to poorer families, both through reforms to reduce corruption and out-of-pocket costs to poor clients and through social safety nets, such as health insurance or loans to cover maternity-related costs. Other less frequently cited programmatic concerns are issues related to service access and quality.

In contrast to this somewhat pessimistic overview of maternal health care in Bangladesh, BMMS data reveal that the estimated maternal mortality ratio was 320 per 100,000 live births for the 1998-2000 period, representing a downward trend of $22 \%$ over the preceding 12 years, ${ }^{9}$ and a level almost half that reported from local studies undertaken during the 1970s and 1980s. ${ }^{23-26}$ A partial explanation for this decline is that even though overall levels of facility-based deliveries and treatment seeking for life-threatening conditions from qualified providers remain low in Bangladesh, women who do seek effective treatment are those with the most severe life-threatening complications. Support for this explanation comes from two surveys conducted in the 1990s, which concluded that met need for emergency obstetric care among Bangladeshi women had increased significantly during this period. ${ }^{27,28}$

Another explanation for this apparent decrease in maternal mortality may lie in the sharp decline in fertility levels that has taken place within Bangladesh over the past three decades. ${ }^{6}$ This decline may have reduced childbearing at higher parities and maternal ages and lowered levels of unwanted pregnancy and abortion. ${ }^{29}$ Only $5 \%$ of maternal deaths in the BMMS data were attributable to abortion, a marked decline from the estimated 18\% of maternal deaths reported in earlier studies. ${ }^{30,31}$ More research on the decline in maternal mortality levels in Bangladesh and its underlying factors is clearly warranted. 


\section{REFERENCES}

1. Wagstaff A and Claeson M, The Millennium Development Goals for Health: Rising to the Challenges, Washington, DC: World Bank, 2004.

2. World Health Organization (WHO), Maternal Mortality in 2000: Estimates Developed by WHO, UNICEF and UNFPA, Geneva: WHO, 2004

3. Ministry of Health and Family Welfare (MOHFW), Bangladesh National Strategy for Maternal Health, Dhaka, Bangladesh: MOHFW, 2001.

4. Thaddeus $S$ and Maine D, Too far to walk: maternal mortality in context, Social Science \& Medicine, 1994, 38(8):1091-1110.

5. Khan MSHK et al., Review of Availability and Use of Emergency Obstetric Care (EmOC) Services in Bangladesh, Dhaka, Bangladesh: Associates for Community and Population Research, 2000.

6. National Institute of Population Research and Training (NIPORT), Mitra and Associates, and ORC Macro, Bangladesh Demographic and Health Survey, 1999-2000, Dhaka, Bangladesh: NIPORT and Mitra and Associates; and Calverton, MD, USA: ORC Macro, 2001.

7. Stewart MK, Stanton CK and Ahmed O, Maternal Health Care, DHS Comparative Studies, Calverton, MD, USA: Macro International, 1997, No. 25 .

8. NIPORT et al., Bangladesh Maternal Health Services and Maternal Mortality Survey 2001, Dhaka, Bangladesh: NIPORT and International Centre for Diarrhoeal Disease Research, Bangladesh (ICDDR,B); and Calverton, MD, USA: ORC Macro, 2003.

9. Hill K et al., How should we measure maternal mortality in the developing world? Bulletin of the World Health Organization, 2006, 84(3): 173-180.

10. Cleland JC and Harlow S, The value of the imperfect: the contribution of interview surveys to the study of gynaecological ill health, in: Jejeebhoy SJ, Koenig MA and Elias C, eds., Reproductive Tract Infections and Other Gynaecological Disorders: A Multi-Disciplinary Research Approach, Cambridge, UK: Cambridge University Press, 2003, pp. 283321 .

11. Fortney JA and Smith JB, Measuring maternal morbidity, in: Berer $\mathrm{M}$ and Ravindran TKS, eds., Safe Motherhood Initiatives: Critical Issues, London: Reproductive Health Matters, 1999, pp. 43-50.

12. Stewart MK and Festin M, Validation study of women's reporting and recall of major obstetric complications treated at the Philippine General Hospital, International Journal of Gynecology \& Obstetrics, 1995 , 48(Suppl.):S53-\$66

13. Ronsmans C et al., Women's recall of obstetric complications in South Kalimantan, Indonesia, Studies in Family Planning, 1997, 28(3): 203-214.

14. Campbell OMR, Measuring progress in safe motherhood programmes: uses and limitations of health outcome indicators, in: Berer M and Ravindran TKS, eds., Safe Motherhood Initiatives: Critical Issues, London: Reproductive Health Matters, 1999, pp. 31-42.

15. NIPORT, Mitra and Associates, and Macro International, Bangladesh Demographic and Health Survey, 1996-1997, Dhaka, Bangladesh: NIPORT and Mitra and Associates; and Calverton, MD, USA: Macro International, 1997.

16. NIPORT, Mitra and Associates, and Macro International, Bangladesh Demographic and Health Survey, 1993-1994, Dhaka, Bangladesh: NIPORT and Mitra and Associates; and Calverton, MD, USA: Macro International, 1994.

17. Barnes-Josiah D, Myntti C and Augustin A, The "three delays" as a framework for examining maternal mortality in Haiti, Social Science $\mathcal{E}$ Medicine, 1998, 46(8):981-993.

18. Filmer D and Pritchett L, Estimating wealth effects without expenditure data-or tears: an application to educational enrollments in states of India, Demography, 2001, 38(1):115-132.

19. Koenig MA, Bloomberg School of Public Health, Johns Hopkins University, Baltimore, MD, USA, unpublished data, 2007.

20. Chowdhury ME et al., Equity in use of home-based or facility-based skilled obstetric care in rural Bangladesh: an observational study, Lancet, 2006, 367(9507):327-332.
21. Afsana K, The tremendous cost of seeking hospital obstetric care in Bangladesh, Reproductive Health Matters, 2004, 12(24):171-180.

22. Nahar S and Costello A, The hidden cost of "free" maternity care in Dhaka, Bangladesh, Health Policy and Planning, 1998, 13(4):417-422.

23. Chen LC et al., Maternal mortality in rural Bangladesh, Studies in Family Planning, 1974, 5(11):334-341

24. Khan AR, Jahan FA and Begum SF, Maternal mortality in rural Bangladesh: the Jamalpur district, Studies in Family Planning, 1986, 17(1): $7-12$

25. Alauddin M, Maternal mortality in rural Bangladesh: the Tangail district, Studies in Family Planning, 1986, 17(1):13-21.

26. Koenig MA et al., Maternal mortality in Matlab, Bangladesh: 1976-85, Studies in Family Planning, 1988, 19(2):69-80.

27. UNICEF, Review of Availability and Use of Emergency Obstetric Care (EmOC) Services in Bangladesh, 1999, Dhaka, Bangladesh: UNICEF, 2001.

28. Bangladesh Institute of Research for Promotion of Essential and Reproductive Health and Technologies (BIRPERHT), A Report on Baseline Survey for Assessment of Emergency Obstetric Care Services in Bangladesh, Dhaka, Bangladesh, BIRPERHT, 1995.

29. Rahman M, DaVanzo J and Razzaque A, Do better family planning services reduce abortion in Bangladesh? Lancet, 2001, 353(9287): $1051-1056$

30. Arifeen SE et al., Centre for Health and Population Research, ICDDR,B, Dhaka, Bangladesh, unpublished data, 2005.

31. Fauveau V et al., Causes of maternal mortality in rural Bangladesh 1976-85, Bulletin of the World Health Organization, 1988, 66(5):643-651.

\section{RESUMEN}

Contexto: Si bien la reducción de los niveles de la mortalidad materna es una meta clave de los Objetivos de Desarrollo del Milenio, en los países de bajos recursos continúan siendo limitadas las posibilidades de lograr asistencia a nivel comunitario para casos de complicaciones obstétricas y de atención materna.

Métodos: En este estudio se presenta un panorama general de datos clave identificados a través de la Encuesta de Servicios de Salud Materna de Bangladesh y de la Encuesta sobre Mortalidad Materna, de 2001, realizadas a mujeres que alguna vez estuvieron casadas, de 13-49 años de edad. Estas encuestas recopilaron datos sobre la prevalencia de las complicaciones obstétricas, sobre el conocimiento que tuvieran las mujeres sobre las complicaciones que constituían riesgo de vida, su conducta para procurar un tratamiento adecuado y sobre las razones por las cuales se demoraban en obtener atención médica.

Resultados: Las mujeres de Bangladesh indicaron que hacian poco pero creciente uso de la atención prenatal, y presentaron bajas tasas de uso de instalaciones de atención de la salud para el parto o de asistencia por parte de un proveedor de salud especializado. Aunque casi la mitad de las mujeres indicó que habían tenido una o más complicaciones durante su embarazo, que ellas habían percibido como complicaciones con riesgo de vida, solo una de cada tres procuró tratamiento médico por parte de un proveedor de salud calificado. Más del setenta y cinco por ciento de las mujeres que tuvieron episodios de complicaciones de convulsiones o un sangrado excesivo, o no procuraron asistencia o recurrieron a un proveedor no calificado. Mencionaron como la causa principal de esta conducta de no procurar atención médica en una situación de complicaciones de riesgo de vida a su preocupación por los altos costos de este servicio. Las pronunciadas disparidades socioeconómicas influyeron en la con- 
ducta observada con respecto a la atención materna, tanto en las zonas urbanas como rurales de Bangladesh.

Conclusiones: A pesar de estas disparidades y brechas de acceso a la atención especializada y eficaz para casos de emergencia obstétrica, se han logrado ciertos avances al reducirse los niveles de la mortalidad maternal. Una mejor atención obstétrica y la disminución de los niveles de fecundidad y de embarazos no deseados han desempeñado un papel esencial al abordar las necesidades de salud materna de las mujeres de Bangladesh.

\section{RÉSUMÉ}

Contexte: La réduction des niveaux de mortalité maternelle figure parmi les principaux objectifs de développement du millénaire, mais la documentation communautaire des complications obstétriques et des comportements de recours aux soins de santé maternelle demeure limitée dans les pays à faibles ressources.

Méthodes: Cette étude présente un aperçu des conclusions principales de l'enquête sur les services de santé maternelle et la mortalité maternelle réalisée en 2001 au Bangladesh parmi les femmes de 13 à 49 ans mariées ou l'ayant jamais été. L'enquête a recueilli des données sur la prévalence des complications obstétriques, la sensibilisation des femmes aux complications graves (mettant leur vie en danger), le recours au traitement et les raisons du recours tardif aux soins médicaux.

Résultats: Les Bangladaises déclarent un recours faible mais grandissant aux soins prénatals, ainsi que de faibles taux d'accouchement en établissement de santé ou avec l'assistance d'un prestataire qualifié. Bien que la moitié des femmes aient déclaré avoir rencontré en cours de grossesse au moins une complication qu'elles percevaient comme grave, une sur trois seulement a fait appel à un prestataire qualifié. Plus de trois quarts des femmes ayant besoin de soins immédiats pour les convulsions ou le saignement excessif n'ont eu recours à aucun traitement ou se sont adressées à un prestataire non qualifié. La raison principale invoquée pour l'absence de traitement des complications graves aura été le souci des frais médicaux encourus. De profonds écarts socioéconomiques ont été observés dans le comportement de recours aux soins maternels dans les milieux urbains aussi bien que ruraux du Bangladesh.

Conclusions: Malgré les écarts d'accès à des prestations d'accouchement qualifiées et de soins obstétriques d'urgence efficaces, un certain progrès a été réalisé vers la baisse des taux de mortalité maternelle. L'amélioration des soins obstétriques et l'affaiblissement des taux de fécondité et de grossesse non désirée ont joué un rôle critique dans la réponse aux besoins de soins de santé maternelle des Bangladaises.

\section{Acknowledgments}

This study used data from the 2001 Bangladesh Maternal Health Services and Maternal Mortality Survey, which was funded by the U.S. Agency for International Development in Bangladesh. The conclusions and opinions expressed here are those of the authors and not necessarily those of the funder. The authors gratefully acknowledge the editing assistance of Lea Hegg.

Author contact: mkoenig@jhsph.edu 